\title{
Katsinovas Framework Prototype Apps Hardware as based Innovation Readiness Level
}

\author{
Raditya Faisal Waliulu, MarcelinusPetrus Saptono, Luluk Suryani, Ery Murniasi
}

\begin{abstract}
Start-up industry, start-up companies go into the moldy lifestyle of young people to form a community to help solve more specific community problems and accurate results. Application testing on community applications is used as alpha 1 before the final release. It is prioritized that the concepts, components and application resolution of serious problems be alleviated. Until the performance. This test is not just an application but a hardware device created by Blueprint. The application of testing uses the framework of Katsinov, up to level 6 where each level explains the concepts, components, completion, enthusiasm or market potential, competition, technology development.
\end{abstract}

\section{Keyword: Katsinova, Prototype, Innovation Readiness Level}

\section{INTRODUCTION}

Indonesian researchers are currently developing rapidly and are supported by the acceleration of the Indonesian Ministry of Research and Higher Education. This form of support is in the form of incentives if it penetrates international journals. In fact, not only that, several other campuses if the results of research pass in the national accreditation journal at least Sinta3 get a reward for boosting the name of the campus and its researchers.

The Indonesian Ministry of Research and Higher Education holds several events to raise campus performance and lecturers among them: simlitabmas (portal for lecturers conducting research and service each year), BSLN (Overseas Seminar Assistance) research results are presented abroad, CPBBT / PBBT (Prospective Business Beginner) Based on technology), the portal puts forward lecturers, students and third parties who are entitled to participate in prestigious events every year.

The presence of Katsinov as a measure of the readiness of directed investment technology has become the development of human resources with international competitiveness and the absorption of the state budget on Indonesian inventors.

Revised Manuscript Received on February 28, 2020.

* Correspondence Author

Raditya Faisal Waliulu*, Department Software Engineering, Major Electro Engineering, PoliteknikKatolik Saint Paul, Sorong, Papua Barat, Indonesia

MarcelinusPetrus Saptono, Department Software Engineering, Major Electro Engineering, PoliteknikKatolik Saint Paul, Sorong, Papua Barat, Indonesia.

Luluk Suryani, Department Software Engineering, Major Electro Engineering, PoliteknikKatolik Saint Paul, Sorong, Papua Barat, Indonesia

Ery Murniasih, Department Software Engineering, Major Electro Engineering, PoliteknikKatolik Saint Paul, Sorong, Papua Barat, Indonesia

(C) The Authors. Published by Blue Eyes Intelligence Engineering and Sciences Publication (BEIESP). This is an open access article under the CC-BY-NC-ND license http://creativecommons.org/licenses/by-nc-nd/4.0/
Obviously, the Head of Sub Directorate of Energy and Transportation Industry Directorate of Industrial Innovation, Directorate General of Strengthening Industrial Innovations at the SEMINAR FUTURE POWERTRAIN TECHNOLOGY SCENARIO event [1], [2], [3], [4], [5].

On future power train technology innovation vehicles for

the Indonesian market by The Directorate General of Strengthening Research and Development, Dr. M Dimyati, said that the Ministry of Research, Technology and Higher Education encouraged 1,071 per one million research population to improve the quality of research results. This is not comparable with the conditions of other countries in Asia and ASEAN. It is hoped that the increase in web-based national \& international journal publishing to 16,000 does not leave the quality of publication standards[6]

Supporting the quality of innovation and research is proven by the presence of a Katsinov framework, by Ristekdikti as a measure of innovation. This framework is free to all prospective entrepreneurs or start-up companies. Another supporting factor of Katsinov is the measurement of target market and future market potential.

In other studies testing was done using the AHP method, while ranking was done using the TOPSIS method. Based on the stages of the study and the criteria for the problem, an example of passing an application is implemented with a calculation to be completed [7].

The presence of Katsinov by Kemenristekdikti financed a number of invention proposals resulting from the research and development process of a number of domestic innovators to be made into innovation products. To determine an invention, it can be called an innovation product using a measuring instrument called the Innovation-Meter Readiness Level Measurement (KATSINOV). Ways to assess and overcome risks must be emphasized in the list of technical planning in order to manage innovation activities. Aspects of risk in this case include the identification of technical risks at the KATSINOV level 1 to 3, identification of risks, especially financial indicators at the KATSINOV levels 4 and 5, as well as the risk assessment of the decision to re-innovate or develop new technologies [8] .

Innovation products include three things: a novelty that causes significant changes, innovation must be able to be used or used by users, and innovation must be able to provide commercial value. Katsinov is closely related to the level of innovation readiness, preparing that this framework will become the foundation of an innovation product ready to be published. The katsinov framework consists of several stages of katsinov 1 through katsinov 6. Each katsinov explains the level of explanation, application, concept to the solution ofthe product to the problem. This will be clearer in Figure 1. 


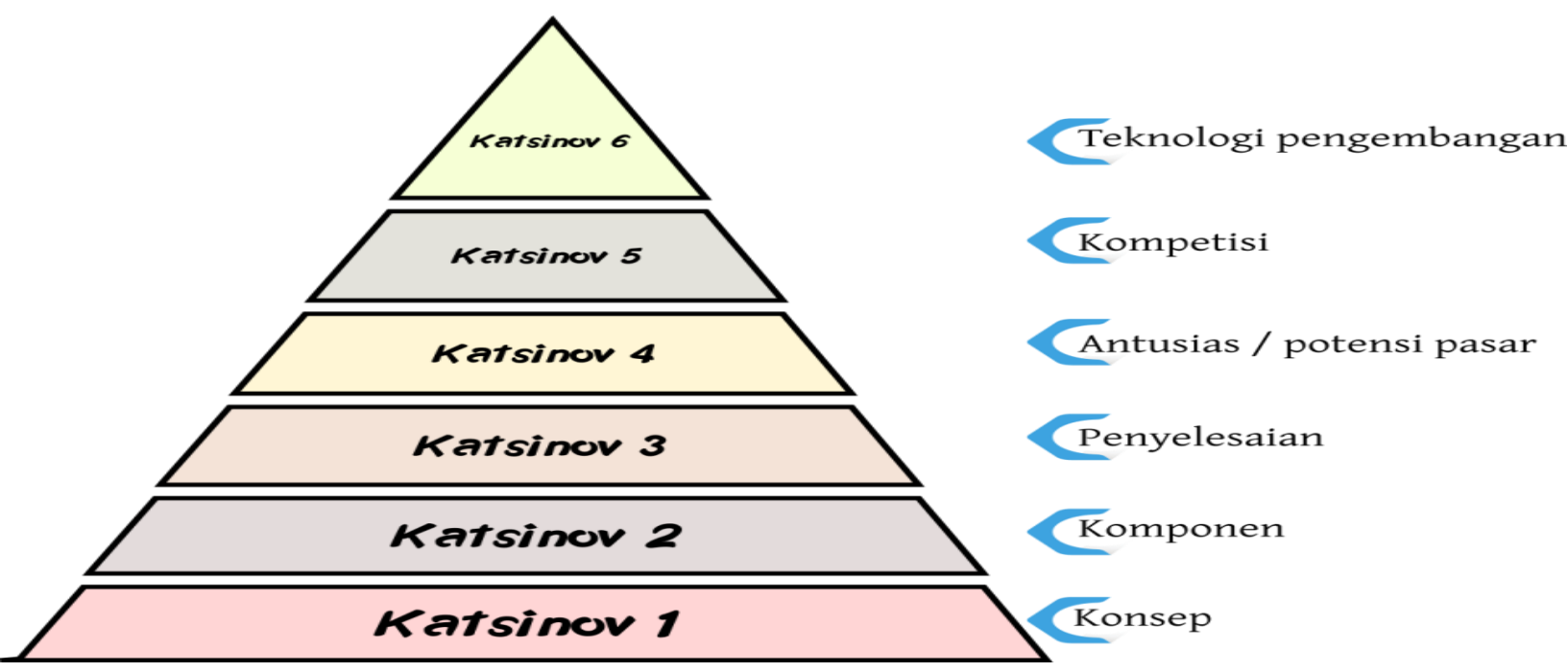

On Fig 1 shows each level katsinov has approximately 22 questions and shows each different focus. This shows the seriousness that the Indonesian government as the Ministry of Research and Technology wants to promote the level of innovation and creativity starting from Universities, Public Colleges to Private Schools.

\section{PROPOSED METHODOLOGY}

\section{a. BLOCK DIAGRAM KATSINOV}

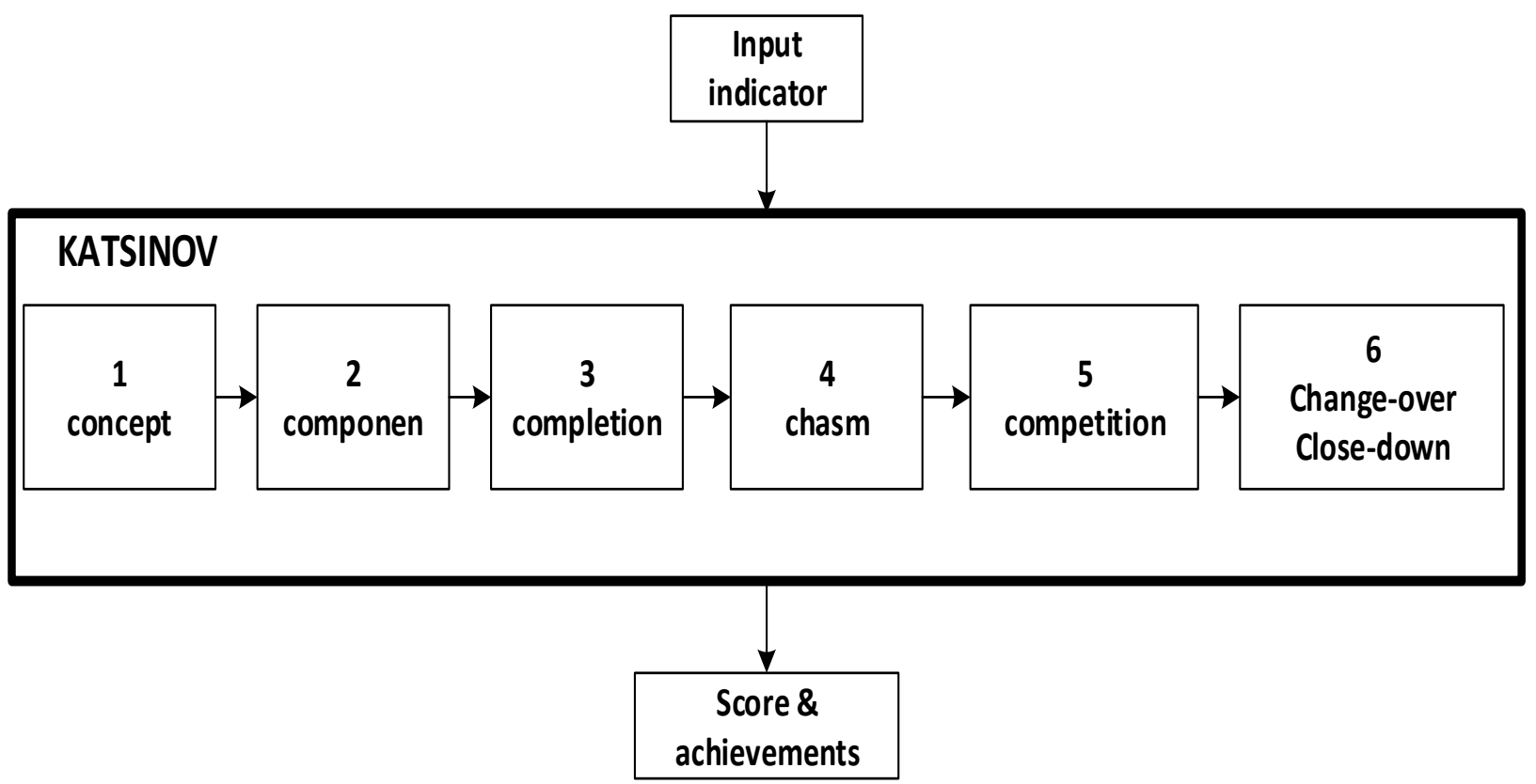

\section{BLOCK DIAGRAM KATSINOV}

\section{Level of measurement of innovation}

b. Algorithm Method Katsinov.

1. Describe the variables katsionov, jml, x, bobot_soal, tot_jawab

2. input the indicator answer that is stored at the value $\mathrm{x}$

3. calculate the jumlah $(\mathrm{jml})=$ bobot_soal ${ }^{*} \mathrm{x}$

4. If Katsinov1 $<150$, then show katsinov score and Katsinov achievements $=$ achieved $/$ not achieved

5. If $150>=$ Katsinov $<150$ then display katsinov score and Katsinov achievements $=$ achieved $/$ not achieved

c. Flowchart Katsinov Method
6. If $250>=$ Katsinov3 $<350$ then display katsinov score and Katsinov achievements = achieved $/$ not achieved

7. If $350>=$ Katsinov $4<450$ then display katsinov score and Katsinov achievements = achieved / not achieved

8. If $450>=$ Katsinov $5<650$ then display katsinov score and Katsinov achievements = achieved / not achieved

9. Finish 


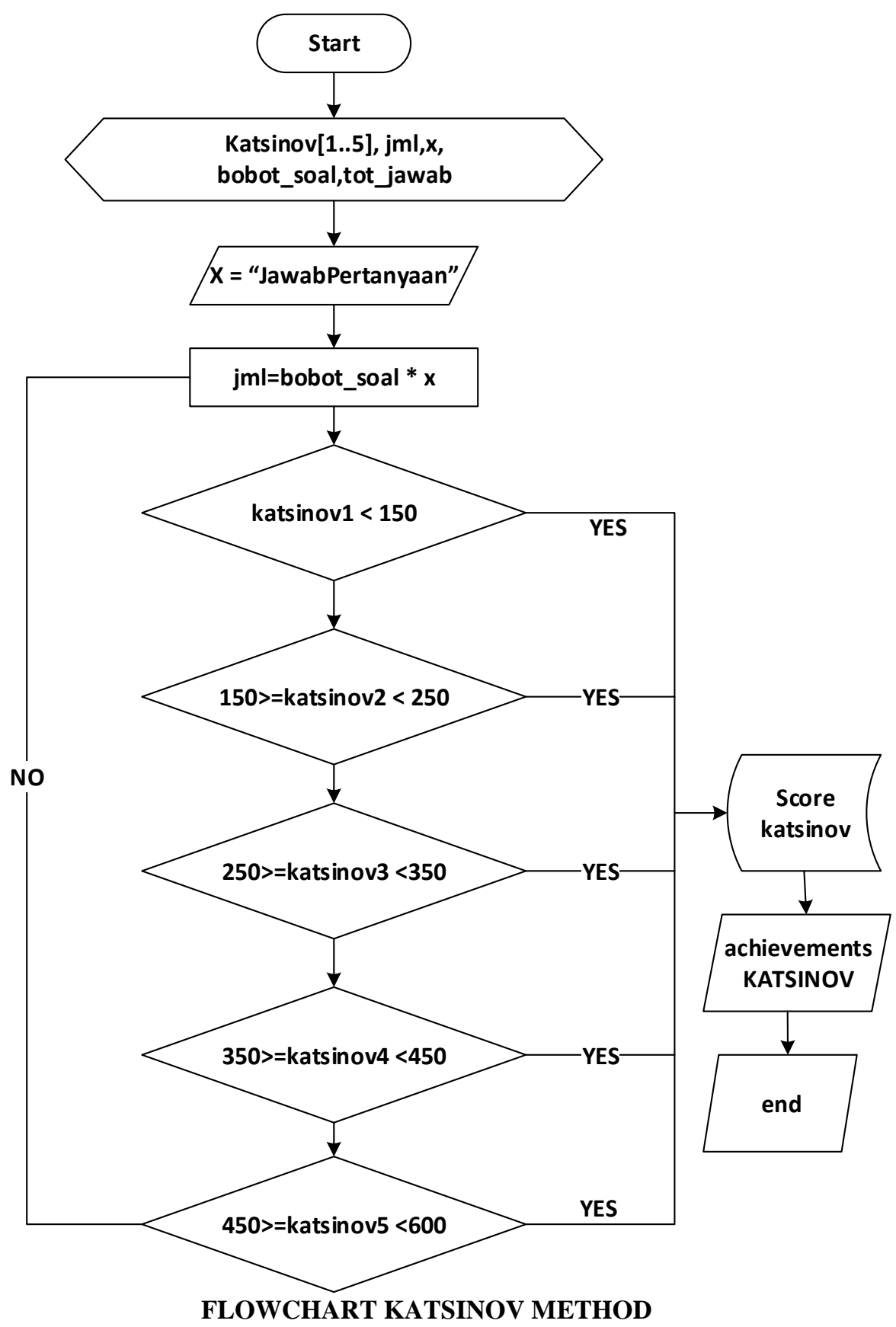

\section{RELATED WORK}

Katsinov is organized into six levels and seven key aspects which include technology, market, organization, partnership, risk, manufacturing, and investment. While the measurement uses Katsinov-Meter, a software that collects several standard statements for each level and displays Katsinov graphically.
The purpose of the formation ofatsatsov 1 through 6 is aimed at the readiness of different innovations. It is expected by the Government of the Republic of Indonesia that this be at a minimum to the Katsinov 3 stage. Because in stages 1 to 3 it the readiness of the concept and the application of the field. The following table explains the purpose of katsinov. 


\section{Katsinovas Framework Prototype Apps Hardware as based Innovation Readiness Level}

Tabel 1 Explain Innovation Readiness Level

\begin{tabular}{|c|c|c|}
\hline & Katsinov & Explain \\
\hline 6 & $\begin{array}{l}\text { change-over nor } \\
\text { close-down }\end{array}$ & $\begin{array}{l}\text { Stage of market downturn, and the determination of two options, namely moving (change-over) with } \\
\text { re-technological innovation, or stopping (close-down) to see the innovation has become obsolete and decided to } \\
\text { get out. }\end{array}$ \\
\hline 5 & Competition & $\begin{array}{l}\text { This is the phase of market maturity, when a market equilibrium is achieved in the absence of meaningful growth } \\
\text { or innovation. }\end{array}$ \\
\hline 4 & Chasm & $\begin{array}{l}\text { Chasm is between early adopters (the enthusiasts \& visionaries) and early majority (the pragmatists). An initial } \\
\text { phase of innovation results has been introduced to the market. At this stage there are challenges and difficulties } \\
\text { whether the product innovation meets the needs or demands of customers when first introduced into the market. }\end{array}$ \\
\hline 3 & Completion & Technology development has been completed and all system functions have been proven in the field. \\
\hline 2 & Component & $\begin{array}{l}\text { Components have been developed and validated, and prototypes have been developed demonstrating the } \\
\text { technology. }\end{array}$ \\
\hline 1 & concept & $\begin{array}{l}\text { The basic scientific principles of innovation have been observed and reported, and critical functions and / or } \\
\text { characteristics have been confirmed through experiments. }\end{array}$ \\
\hline
\end{tabular}

Each question in Katsinov has aspects so that innovation products do not come out of tupoksi that will be marketed later. Some of them ask about technology aspects (T), market aspects (M), manufacturing aspects (Mf), organizational aspects (O), partnership aspects (P), investment aspects (I), risk aspects $(\mathrm{R})$.

In the matter of katsinov after the aspect and focus of the next field the weighting which is characteristic for the product to be good and directed. The following sample katsinov 1 weighting as a whole is shown in Figure 2.

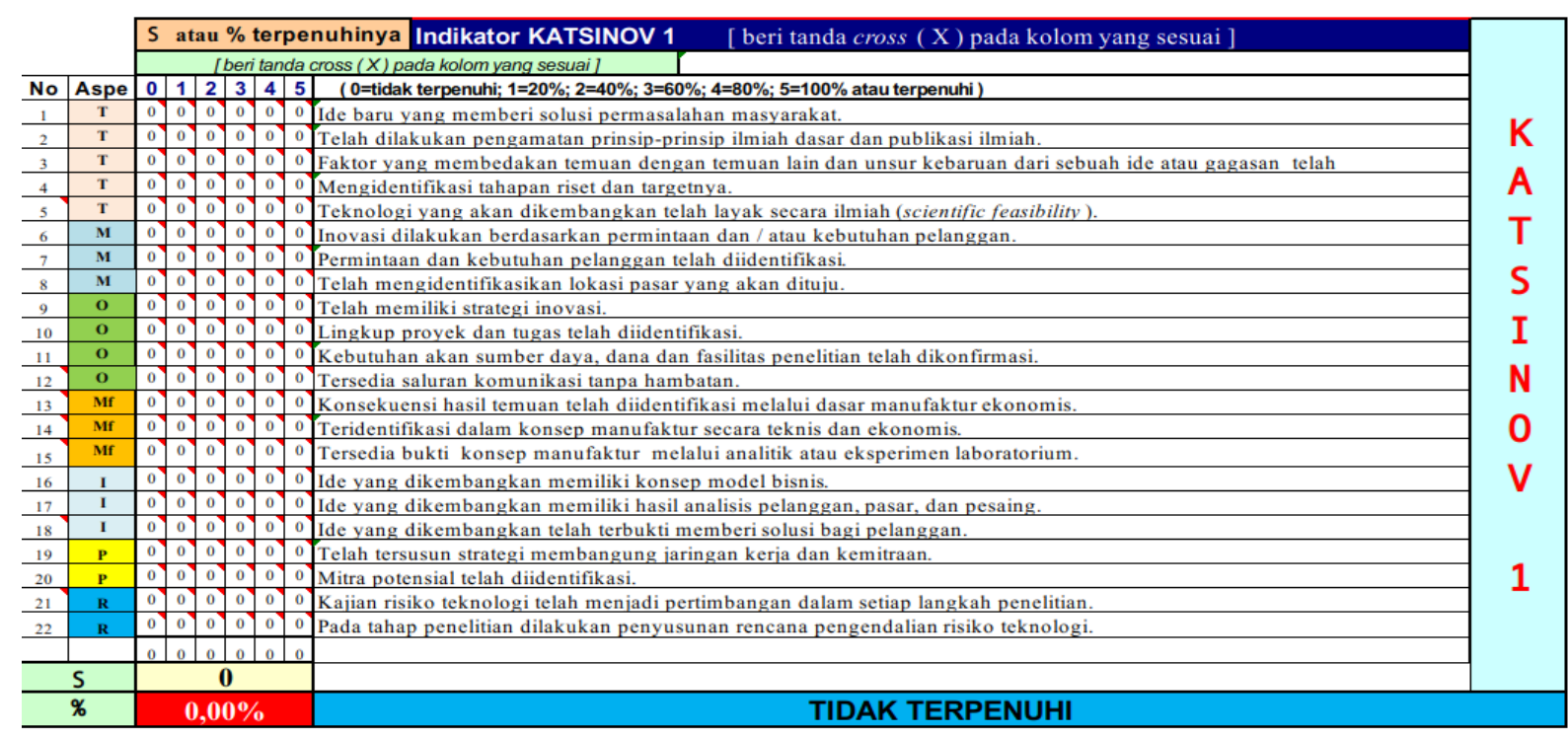

Figure 2. katsinov 1

The weights in katsinov 1 to 6 . are overall formulated in the following equation:

$$
\begin{gathered}
V=(N x O)+(N x 2)+(N x 3)+(N x 4)+(N x 5) \\
L=\frac{V}{S x 5}
\end{gathered}
$$

$\mathrm{N}$ : Number of selected weighting values

I : Katsinov level selected

S : Total task

\section{RESULT}

Each question in katsinov has a weighting value between 0 to 5 interpreted with the letter $\mathrm{N}$. The value of 0 , very less even 5 is very satisfying. The weighting of values will be multiplied and added up to each problem ... at the end of the
$\mathrm{S}=$ Numbers of question katsinov

Insert equations (1) and (2) in the following formula:

$$
\sum_{k=1}^{6}=L x 100 \%
$$

operation will be divided by $100 \%$ as a form of presentation of the final value. Katsinov 1, has a $70 \%$ graduation threshold to reach katsinov 2. It is closely related that Katsinov 1 tests the concept of tool knowledge and applies to problems. 
Tabel 2. THRESHOLDKATSINOV

\begin{tabular}{|c|c|c|}
\hline Item & Soal & Minimal \\
Kelulusan
\end{tabular}

Calculation if it is assumed an innovator is able to prove the concept and application in the field (Katsinov'sself

assessment 1 to Katsinov 3). Given a value that has been created and filled, then the results are displayed as follows:

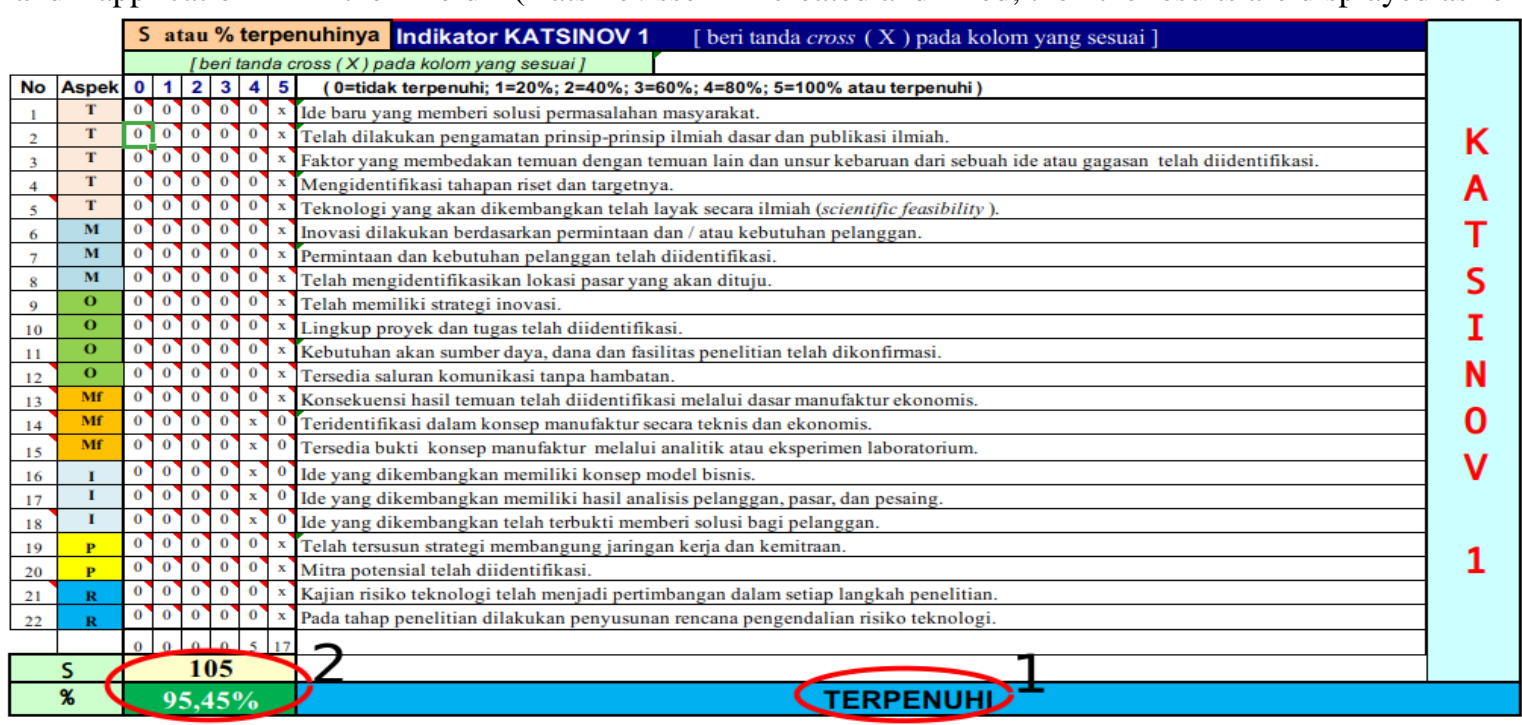

Figure 3. katsinov 1

assessing Fig. 3, shown below

$$
\begin{gathered}
L=\frac{V}{S \times 5} \\
=\frac{105}{22 \times 5}=0,9545 \\
\sum_{k=1}^{k=6}=L x 100 \%=95,45 \%
\end{gathered}
$$

$$
\begin{gathered}
V=(N \times 0)+(N \times 1)+(N \times 2)+(N \times 3)+(N \times 4) \\
\quad+(N \times 5) \\
=(0 \times 0)+(0 \times 1)+(0 \times 2)+(0 \times 3)+(5 \times 4) \\
\quad+(17 \times 5) \\
=0+0+0+0+20+85=105 \\
\quad S=22
\end{gathered}
$$

Consider, to fit the equation (2)

Result katsinov $1, \mathbf{K} \mathbf{1}=>\mathbf{8 0} \%$ = continue to katsinov 2

$$
\sum K 1=95,45 \%
$$

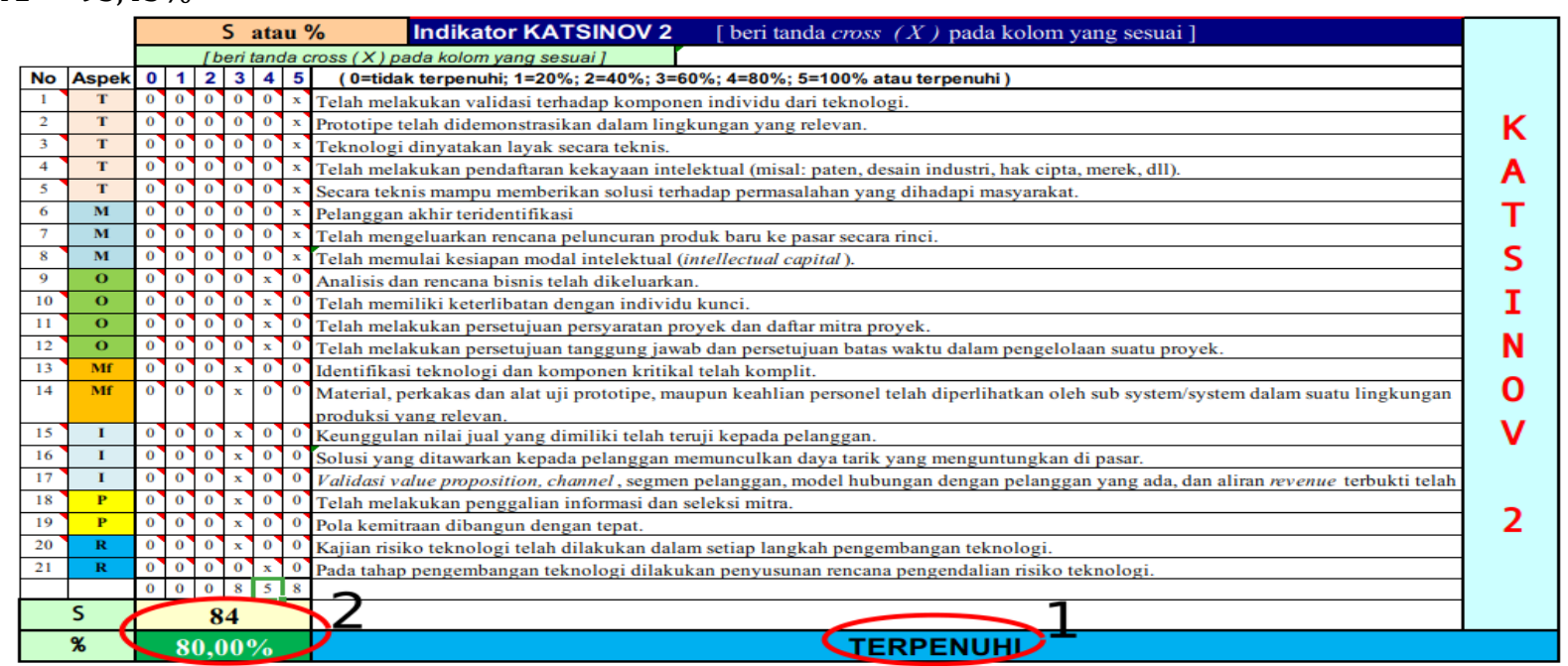

Figure 4. katsinov 2 
Katsinovas Framework Prototype Apps Hardware as based Innovation Readiness Level

Assessing fig.4, shown below

$$
\begin{gathered}
V=(N \times 0)+(N \times 1)+(N \times 2)+(8 \times 3)+(5 \times 4) \\
+(8 \times 5) \\
=(0 x 0)+(0 x 1)+(0 x 2)+(24)+(20)+(40) \\
=0+0+0+24+20+85=84 \\
S=21
\end{gathered}
$$

Consider, fit in equation (2)

$$
L=\frac{V}{S \times 5}
$$

$=\frac{84}{21 \times 5}=0,8$

$$
\sum_{k=1}^{k=6}=L x 100 \%=80 \%
$$

Result katsinov 2, K2=>80\% = continue to katsinov 3

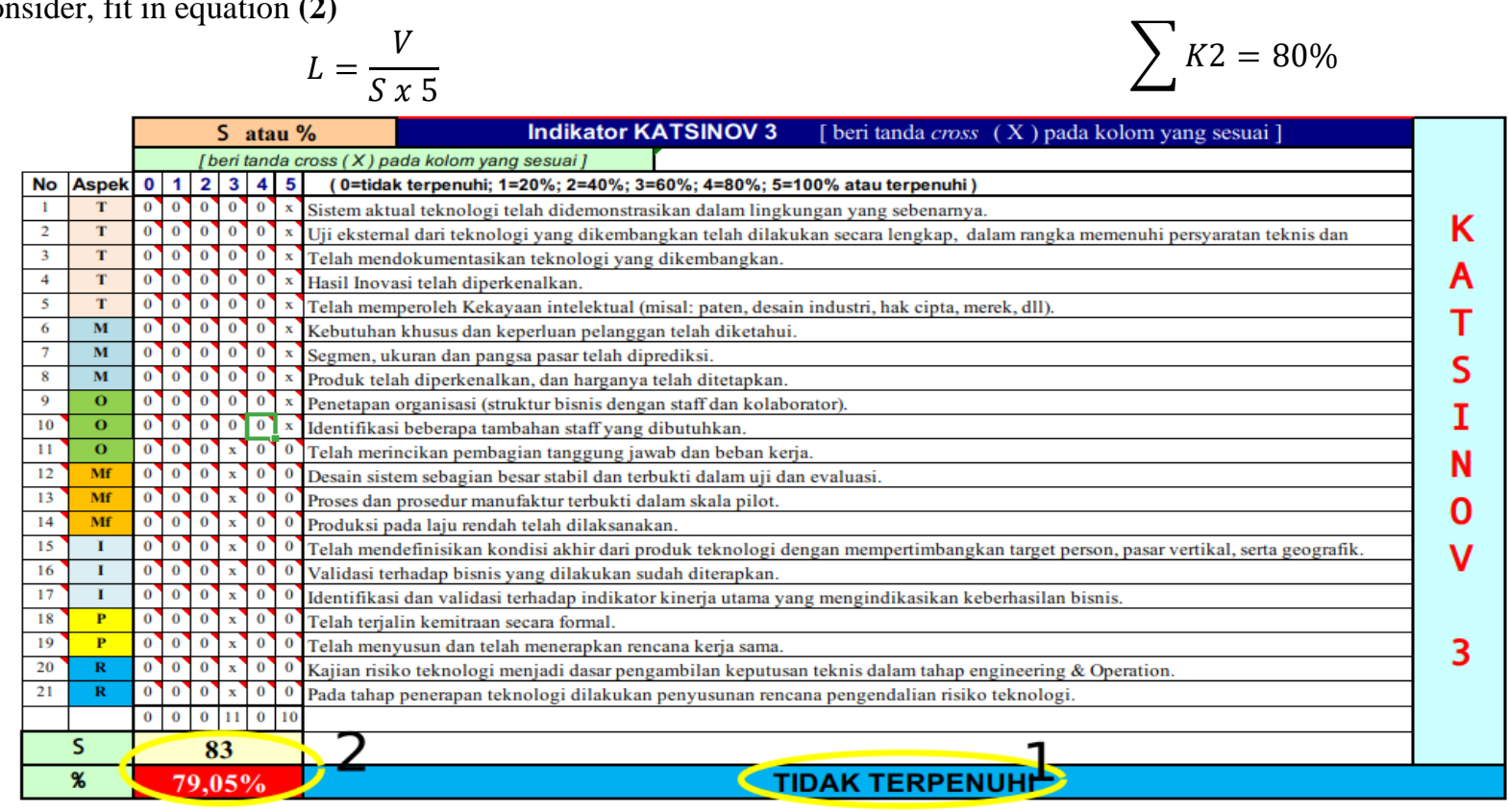

Figure 5. katsinov 3

Asesing fig.5, shown below

$$
\begin{gathered}
V=(N \times 0)+(N \times 1)+(N \times 2)+(N \times 3)+(N \times 4) \\
\quad+(N \times 5) \\
=(0 x 0)+(0 x 1)+(0 \times 2)+(11 \times 3)+(0 x 4) \\
\quad+(10 \times 5) \\
=0+0+0+33+0+50=83 \\
\quad S=21
\end{gathered}
$$

Consider, fit in equation (2)

$$
\begin{gathered}
=\frac{83}{21 \times 5}=0,7905 \\
\sum_{k=1}^{k=6}=L x 100 \%=79,05 \%
\end{gathered}
$$

result of katsinov $2, \mathrm{~K} 3=<80 \%=$ conclusion halt at katsinov 3

We got formula like

$$
\sum K 3=79,05 \%
$$

$$
\sum K 1+K 2+K 3=95,45+80+79,05=254,5
$$

Katsinov innovation potential collected was 254.5 in katsinov 3.

\section{CONCLUSION AND FUTURE WORK}

Achievements from measurements up to katsinov 3. This proves that the results obtained include the concept has been mastered, from the concept of the problem to the problem and its solution. This is indicated by the value of katsinov 1 getting a score of $95.45 \%$. Obviously getting an almost perfect score above average.

Katsinov 2, the score obtained $80 \%$ is the standard of success. This proves that the protoype component was developed according to field problems and was validated. However, the solution of the problem has not been reached in accordance with the initial expectations. Revalidation of problem solving is needed.

Katsinov3, the score obtained $79.05 \%$ is a low standard and has not yet achieved success in the application of the actual environment. What has been proven remains to be done evaluating the prototype, the system and is supported by reports by tester users. It is expected to pass the Katsinov 3 selft assessment to Katsinov 4.

From all this it is found that the components have been developed and validated, and the prototype has been developed demonstrating the technology is one of several that must be measured in measuring innovation. Some of them are the concepts and designs of Katsinov thinking and measurement practices (measuring tools) and the understanding of Business Model Canvas (BMC).

\section{ACKNOWLEDGMENT}

Gratitude to the Saint Paul Catholic Polytechnic has sponsored research into the application of Katsinov to innovation products. It is hoped that the creation of these tools can become self-assessment and be an encouragement to develop themselves and applications for the better 


\section{REFERNCE}

1. (2018, Mei)

Risbang

Risetdikti. http://risbang.ristekdikti.go.id/publikasi/berita-media/jumlah-peneliti-i ndonesia-masih-sedikit/

2. Mogee, M. E. (1991). "Technology policy and critical technologies: a summary of recent reports (Vol. 3). National Academies.

3. Interlaboratory Working Group on Energy-Efficient, Low-Carbon Technologies, \& United States. Department of Energy. (1997). Scenarios of US carbon reductions: Potential impacts of energy technologies by 2010 and beyond. Office of Energy Efficiency and Renewable Energy, US Department of Energy.

4. Schneider, A. H., Seleme, L. D. B., Rodrigues, F. F., de Souza, M., \& de Carvalho, H. G. (2012). " in Scenario Building: Methodological Advancements and a Foresight Study of the Automotive Industry in Brazil". In Technological, Managerial and Organizational Core Competencies: Dynamic Innovation and Sustainable Development (pp. 302-325). IGI Global.

5. Hacking, N., Pearson, P., \& Eames, M. (2019). "Mapping innovation and diffusion of hydrogen fuel cell technologies: Evidence from the UK's hydrogen fuel cell technological innovation system, 1954-2012". International Journal of Hydrogen Energy, 44(57), 29805-29848.

6. Wiwiek Yuliani, "PENDANAAN INOVASI (instrumen kebijakan inovasi) dalam Inovasi Teknologi Power Train Kendaraan Masa Depan Untuk Pasar Indonesia," Direktorat Invovasi Industri Kementrian Riset, Teknologi dan Pendiidkan Tinggi, Jakarta, Seminar Inovasi 2019.

7. Desi Ratna Sari, Agus Perdana Windarto, Dedy Hartama, and Solikhun, "Sistem Pendukung Keputusan untuk Rekomendasi Kelulusan Sidang Skripsi Menggunakan Metode AHP-TOPSIS," Jurnal Teknologi dan Sistem Komputer, vol. 6, no. 1, pp. 1-6, Januari 2018.

8. Ph.D.Ak Prof. H. Mohamad Nasir, "Laporan kinerja Instansi Pemerintah Kementrian Riset, Teknologi dan Pendidika Tinggi 2017," Februari, pp. 114-120, 2018.

\section{AUTHORS PROFILE}

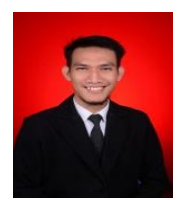

Raditya Faisal Waliulu*, Department Software Engineering, Major Electro Engineering, PoliteknikKatolik Saint Paul, Sorong, Papua Barat, Indonesia. Email: waliulu.raditya@gmail.com.

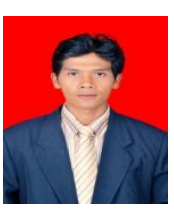

Marcelinus Petrus Saptono, Department Software Engineering, Major Electro Engineering, Politeknik Katolik Saint Paul, Sorong, Papua Barat, Indonesia. Email: marcell.poltekstpaul@gmail.com

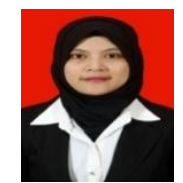

Luluk Suryani, Department Software Engineering, Major Electro Engineering, Politeknik Katolik Saint Paul, Sorong, Papua Barat, Indonesia. Email: Luluk.suryani@gmail.com.

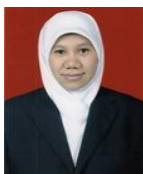

Ery Murniasih, Department Software Engineering, Major Electro Engineering, Politeknik Katolik Saint Paul, Sorong, Papua Barat, Indonesia. Email: ery.murniyasih@gmail.com 